\title{
Deconstructing the Turkish Military's Popularity
}

\begin{abstract}
Why is the military so popular in Turkish society? By using World Values Survey data, this study explores the impact of several political, social, and personal factors on societal confidence in the military. Empirical results indicate that there is a significant variance in confidence in the military across certain political groups. Although the military's popularity is high among nationalists, it is rather limited among pro-Islamic and pro-Kurdish groups. Interestingly, however, religion cuts both ways in the formation of confidence in the military. Pro-Islamic groups do not have much confidence in the strictly secular military, but being a devout Muslim does not reduce the military's popularity. Another interesting finding is that trust in civilians and support for democracy do not necessarily reduce military's popularity. A brief discussion of some implications of these findings for the civil-military relations and prospects for the consolidation of democracy in the Turkish Republic is also provided.
\end{abstract}

Keywords: Turkish military's societal popularity; civil-military relations; pro-Islamic; pro-Kurdish; ordinal-probit analysis

\section{Introduction}

W hy is the military so popular in Turkish society? This is an important question, because as Table 1 below indicates, the Turkish military enjoys a high degree of public trust while societal trust in civilian institutions such as the government, the parliament, and political parties remains relatively limited.

Interestingly, not only for ordinary citizens but also for certain professional groups, such as academics, the military remains as the most trusted institution. ${ }^{1}$ Thus, it is fair to suggest that Turkish society in general views the military as "the most egalitarian, non-politicized, and professional public institution compared with the political class that was often unstable, corrupt and unreliable." 2 In addition, the popularity of the military in Turkey is much higher than militaries in some other countries. For instance, $61 \%$ of Turkish respondents have a "great deal of confidence" in the military, while

Author's Note: I would like to thank William Hale, Jay Fisher, Güneş Ertan, two anonymous reviewers, and the editor for very helpful comments and suggestions on the earlier versions of the article. Please address all correspondence to Dr. Zeki Sarigil at sarigil@bilkent.edu.tr. 
Table 1

Societal Confidence in Turkish Political Institutions (1999-2000)

\begin{tabular}{lc}
\hline Institution & Confidence (\%) \\
\hline Military & 86.2 \\
Police & 68.7 \\
Government & 45.4 \\
Parliament & 41.5 \\
Press & 33.6 \\
Political Parties & 27.8 \\
\hline
\end{tabular}

Note: Only answers of "great deal of confidence" and "quite a lot of confidence" were counted. Source: World Values Survey, 1999-2000.

this rate is $33 \%$ in the United States, $17 \%$ in Canada, and only $7 \%$ in Spain. ${ }^{3}$ Thus, it is clear that, compared to other militaries, the Turkish military enjoys a high degree of popularity in society. ${ }^{4}$

The main motivation of this study is to investigate the factors that shape this public confidence in the Turkish military, which is a surprisingly under-investigated issue. The existing literature acknowledges high societal trust in the Turkish military, but we know little about the reasons for and dynamics behind this political phenomenon. This issue deserves more scholarly attention, because it is a fact that one characteristic of Turkish politics has been the strong influence of the military on civilian politics. ${ }^{5}$ However, it is puzzling that military interventions do not seem to damage its popularity or its prestigious position in society. ${ }^{6}$

It should be acknowledged that since the Turkish Republic was recognized as a candidate state for European Union (EU) membership in 1999 (Helsinki Summit), significant changes have taken place in Turkish civil-military relations, which limited the political powers of the military to a certain extent. ${ }^{7}$ However, the Turkish military is still politically the most powerful military within NATO and thus continues to exert a significant degree of influence on civilian politics. One recent example of the military's attempt to intervene in civilian politics was its reaction to a disputed vote in the Turkish parliament on a presidential candidate. When the ruling Adalet ve Kalkınma Partisi (Justice and Development Party, AKP), which is an offshoot of the banned Islamist Refah Partisi (Welfare Paty, 1983-1998) and Fazilet Partisi (Virtue Party, 1997-2001), nominated Foreign Minister Abdullah Gül as its candidate for the presidency, the military perceived this as an act contrary to secular principles. The military believed that, Abdullah Gül, whose wife wears a headscarf, had roots in political-Islam and his presidency would undermine secular values. As a reaction to his nomination, on April 27, 2007, the Office of Chief of the General Staff sent a harsh warning to the government from its "website," stating: 
The problem that emerged in the presidential election process is focused on arguments over secularism. Turkish Armed Forces are concerned about the recent situation. It should not be forgotten that the Turkish Armed Forces are a party in those arguments, and absolute defender of secularism....It will display its attitude and action openly and clearly whenever it is necessary. ${ }^{8}$

This incident demonstrates that the civilian control of the military is still not a completely resolved issue in the Turkish Republic, which is also an important matter in the process of Turkey's accession to the EU. ${ }^{9}$

The societal popularity of the Turkish military is taken as given in the existing literature, but we have rather limited empirical knowledge of the factors behind this important subject. It is a significant issue because the popularity of the military would have some direct consequences for the civil-military relations. As it is suggested, "the standing of the officer corps and its leaders with public opinion and the attitudes of broad section or categoric groups in society toward the military are key elements in determining military influence." 10 Thus, the military's prestige and popularity in society might be "vital to its ability to exert political leverage." ${ }^{11}$ This is because a high level of societal trust contributes to the military's ability to legitimize its intervention in politics. ${ }^{12}$ Put differently, the military's popularity in the society creates a favorable environment for the military to become involved in civilian politics. ${ }^{13}$ Moreover, the military's popularity and prestigious position may reinforce the civilians' sense of powerlessness, ${ }^{14}$ which in return provides more space for the military to maneuver when attempting to shape civilian politics. Therefore, having a better sense of the factors that shape the military's societal popularity is important for enhancing our understanding of Turkish civil-military relations and the prospects of achieving a consolidated democracy in Turkey. With these motivations and goals, this study raises following questions: What factors explain the military's popularity in Turkish society? How does it vary across certain political groups? What conclusions can be drawn for the prospects of the democratic consolidation in Turkey?

Findings: By using World Values Survey data (Turkey 2000), this study explores the impact of several political, social, and personal factors on confidence in the military. The empirical findings indicate that the military's popularity should not be taken for granted. Although it is high among nationalists, it is rather limited among pro-Islamic and pro-Kurdish groups. Interestingly, however, religion cuts both ways in the formation of confidence in the strictly secular military. Pro-Islamic groups do not have much confidence in the secular military, but being a devout Muslim does not reduce the military's popularity. Another interesting finding is that increasing trust in civilians and support for democracy does not necessarily reduce the military's popularity, which indicates that society in general views the military as part of the political system and as the guardian of democracy. Finally education level is negatively associated with the confidence in the military while other factors, such as fulfilling military service, income level, gender, and life satisfaction do not have any significant impact. 
The article proceeds as follows. The following section provides a theoretical discussion and hypothetical expectations. The research design section tests those hypotheses. Some implications of the empirical findings for civil-military relations and prospects for the consolidation of democracy in the Turkish Republic are presented in the conclusion.

\section{Theoretical Discussion and Hypotheses}

With respect to the political factors, three important sentiments are taken into account: pro-Islamic, pro-Kurdish, and nationalism. The Turkish Republic experienced the rise of identity politics in the 1990s. The revival of Islamic and Kurdish identities in particular created major challenges to the secular, centralized, and unitary Turkish nation-state during this period. ${ }^{15}$ The military, which presents itself as the ultimate guardian of the nation-state, national unity, and Kemalism (secularist and republican principles in particular) vis-à-vis internal (e.g., fundamentalism, separatism) and external (e.g., foreign attack) threats, ${ }^{16}$ has been highly concerned about these rising challenges and took a tough stance against pro-Islamic and pro-Kurdish groups and actions. Within such a political environment, there should be some variance across these political groups in their trust in the military.

Political Islam: In the Turkish political system, the strongly secular military has always been concerned about political Islam and kept a close watch on Islamic-oriented political parties and societal groups. ${ }^{17}$ The rise of political-Islam in the 1990s led to a power struggle between the military and religious parties. ${ }^{18}$ For instance, in 1997, an ultimatum from the military led to the resignation of the coalition government headed by pro-Islamist Necmettin Erbakan, the leader of openly Islamist Refah Partisi (RP) (Welfare Party, 1983-1998). The military believed that the RP was using religion for political ends. Thus, the military considered certain actions and policies of the Refahled coalition government as a significant threat to the secular nature of the Republic. As a result, the military criticized the government during an MGK (National Security Council) meeting, which took place on February 28, 1997, and requested that the government implement eighteen specific, concrete measures against ascending political Islam. After facing increasing pressure from the military-bureaucratic elite and from certain republican, secular civil society organizations, some of which were activated by the military, the government had to resign in June 1997. This intervention as well as its involvement in the 2007 presidential election clearly indicates the uneasy relations between the military and political Islam. Therefore, one might expect that:

$H_{1}$ : It is less likely for pro-Islamic individuals to have high level of confidence in the military.

Yet, this expectation may not hold for pious individuals. It is important to distinguish the impacts of "being a religious person" vs. "having a pro-Islamic attitude" 
on confidence in the military, because it is fair to argue that being a religious person does not necessarily mean being pro-Islamic. Thus, confidence in the military might be lower among politically active Islamic groups because of the military's wrath against political-Islam in the 1990s, but this may not be the case for devout Muslims. In other words, the military's strict commitment to secularism and its strained relations with pro-Islamic groups may not affect pious individuals' attitudes vis-à-vis the military. Furthermore, although the Turkish military is suspicious of politically active Islamic actors, the Turkish military also presents itself as the "pious defender of the nation and the Muslim faith." As Kaplan observes:

\begin{abstract}
Although political rhetoric in Turkey often assumes a sharp difference between a secular and a religious vision of the nation, the military ideals that children learn at school suggest a more ambiguous relationship between these two adversarial worldviews. In fact, the curriculum emphasizes that the Turkish soldier is a pious defender of the nation. Clearly, Islamic rhetoric is used to valorize the military heritage. . ${ }^{19}$
\end{abstract}

Therefore, this study includes two religion-related, but distinct, factors as predictors of confidence in the military: pro-Islamic attitude and religiosity. Pro-Islamic attitude, here, refers to support for Islamist parties, which advocate changing the secular system and bringing rule by shari'a (Islamic law) instead. ${ }^{20}$ To measure it, this study uses support for the pro-Islamist Fazilet Partisi (Virtue Party, 1997-2001), ${ }^{21}$ the only pro-Islamist party operating at the time of the survey. Although Fazilet had moderate views on several issues compared to its predecessor Islamist Refah Partisi, it is labeled as one variant within political Islam. ${ }^{22}$ Furthermore, it is also shown that after Refah's closure, Fazilet became the main party for pro-Islamic voters, who were more likely to be supportive of shari'a. ${ }^{23}$

On the other hand, religiosity refers to the significance of religion in one's life, which may not necessarily create a pro-Islamic attitude in the political realm. In measuring this concept, individuals' self-evaluation about the importance of religion in their lives is used (see Appendix A). Although using this survey question may not be the best way to operationalize the concept of "religiosity," it would still give us some sense of it.

Pro-Kurdish Attitude: The Kurdish problem has been another crucial issue in Turkish politics. As President Turgut Özal (1989-1993) stated, it has been the most significant problem in the history of the Republic. ${ }^{24}$ In the last two decades, Kurdish separatism has emerged as one of the biggest challenge to the Turkish state and democracy. ${ }^{25}$

The Turkish Republic emerged as a nationally homogenous, modern, secular, and centralized nation state in the early 1920s from the remnants of the Ottoman Empire. The newly established Turkish Republic simply rejected multiculturalism. Ethnocultural distinctions among the Muslim population were ignored, and any public expression of those differences was suppressed. The ultimate goal was to "create" the Turks of the new nation state. ${ }^{26}$ The state's suppression and denial of the Kurdish 
identity, however, created reactionary movements in the Republic. During the 1920s, and 1930s, the young Republic was challenged by several Kurdish uprisings with strong ethno-religious elements. Major ones were: Shaykh Said Rebellion (1925); the A $\breve{g r} 1$ Revolt (1930); and the Dersim (Tunceli) Revolt (1937). Religion and tribal connections were an important component in these early uprisings, which were primarily a reaction against the Republic's attempts at centralization and secularization.

In the 1990s, the Kurdish movement, led by the Partiya Karkaren Kurdistan (PKK, Kurdistan Workers Party, established in 1978), became more nationalist-separatist, more organized, more challenging, more assertive, and also much more violent. In the early 1980s, an armed conflict started between security forces and Kurdish separatists. The intensity of this armed conflict increased in the mid-1990s. From 1984 to 1999, the number of people killed was estimated to be about 30,000 (half of them PKK members, one-fourth civilians, and one-fourth security members).

It is also important to note that in the 1999-2005 period, primarily due to EU pressure, the Turkish Republic adopted several constitutional and legislative reforms that enhanced the cultural rights of Muslim ethnic groups, primarily Kurds (e.g., allowing broadcasting in Kurdish and private language courses). These path-breaking changes brought Turkey much closer to EU standards in terms of human rights practices. ${ }^{27}$ These changes marked a significant shift in the official attitude vis-à-vis the Kurdish issue. That said, the Turkish state has avoided defining the issue as an "ethnic" or "political" problem. Using the words of Somer, "while Kurdish difference and its distinct identity were increasingly acknowledged [in the period from 1984-1998], mainstream beliefs regarding the desirability or acceptability of any Kurdish ethnic-cultural and political rights and expressions did not necessarily change." ${ }^{28}$ The rejection of the Kurdishness of the Kurdish question did not make the problem disappear, of course, but the Turkish side framed the problem as one of regional terrorism resulting from socioeconomic backwardness in southeastern Turkey (e.g., feudal, tribal social structures, limited economic growth, and unemployment in the region).$^{29}$ Turkish authorities also argued that several external actors, such as neighboring and some European countries, have supported Kurdish terrorism/separatism to destabilize and divide the Turkish Republic. ${ }^{30}$ In other words, for the Turkish officials, the problem was primarily a security problem. As a result of this perception, until recently, the state response was based exclusively on harsh military measures. ${ }^{31}$ This was another factor that enhanced the role of the military in civilian politics in the 1990s. ${ }^{32}$ Given this political atmosphere, one might expect that:

\section{$\mathrm{H}_{2}$ : Among pro-Kurdish individuals, the popularity of the military should be lower.}

Due to a lack of a direct question about ethnic origin or attitude on the Kurdish problem, it is difficult to identify whether or not the respondent has a pro-Kurdish stance. Instead, I used a proxy survey question to do that. Because pro-Kurdish groups 
are more likely to vote for pro-Kurdish parties ${ }^{33}$ I used voting behavior as a proxy for pro-Kurdish tendencies (see Appendix A). Although this is not the best way of measuring pro-Kurdish tendencies, it does serve our purpose, which is to assess the popularity of the military among politically active pro-Kurdish groups.

Nationalism: Nationalist feelings should also matter in the formation of confidence in the military because as Jenkins observes, "most Turks still see the military and military virtues as being inseparable from the concept of Turkishness." ${ }^{34}$ The notion of military-nation or nation-in-arms is widespread in Turkish society. ${ }^{35}$ Thus, the military is perceived as the symbol of nationhood and national pride ${ }^{36}$ and therefore as the ultimate guardian of national ideals and interests. Furthermore, because the Turkish Republic is located in a rather unstable region, surrounded by political, religious, ethnic, and economic conflicts and tensions in the Middle East, Caucasia, and Balkans, the Turkish military is considered by nationalists as the guarantor of national interests and state survival. It is also important to note that, most Turkish nationalists have a significant degree of support for the military's fight against the PKK. All of these factors should boost the military's popularity among nationalists. So, one might expect that:

\section{$H_{3}$ : It is more likely for "nationalists" to have a high level of confidence in the military.}

Ideology (left vs. right) might also play some role in trust or distrust in the military. For instance, Huntington suggests that there is an inherent contrast and conflict between the military ethic and liberalism, fascism, and Markism; inherent similarity and compatibility between military ethic and conservatism. ${ }^{37}$ In Turkish case, it is observed that among some extreme leftist groups, the military's popularity has been low. ${ }^{38}$ However, this may not be the case for the most extreme groups on the right side of the political spectrum (e.g., ultranationalists).

In terms of social factors, this study looks at whether individuals' democratic attitudes, trust in civilians, and socialization through military service have any impact on trust in the military. I expect that as trust in democracy and democratic processes increases, it would be less likely for people to appeal to alternative sources of governance. Thus, another proposition is that:

$H_{4}$ : As trust in and support for democracy and democratic processes increase, the confidence in and appeal to the military would decline.

Trust or distrust in the political system and in civilians might also shape societal trust in the military. As it is suggested:

Another aspect of Turkish society that helps reinforce the military's informal position of power is the popular societal distrust in the political system, which has been fragmented since the inception of multiparty rule in 1950 . . The very fact that politicians do not 
speak in a single voice and that the political system has been plagued, intermittently, by chaos and inefficiency since its inception are leading justifications for public support of the military. ${ }^{39}$

If it is the case that Turkish society in general "see the army as a kind of safety net that will protect the nation from the predatory behavior of its politicians," ${ }^{40}$ then one might hypothesize that:

\section{$H_{5}$ : Those who distrust civilian politicians would be more likely to trust the military.}

Conscription as a socializing mechanism: It is argued that other than providing security, militaries also function as a "school." In other words, militaries transmit certain values and norms to citizens. ${ }^{41}$ This military-as-school approach treats soldiers as "blank slates on which the military can inscribe values, both great and small." ${ }^{42}$ As one Brazilian proponent of the conscription suggested, "The cities are full of unshod vagrants and ragamuffins. . For these dregs of society, the barracks would be a salvation. The barracks are an admirable filter in which men cleanse and purify themselves: they emerge conscientious and dignified Brazilians." ${ }^{43}$

Turkish society is even more suitable for such military socialization. Since 1927, military service has been mandatory. A majority of young Turks view joining the military as fulfilling a sacred national duty or a heroic mission (vatan borcu-the debt to the Turkish nation and land). ${ }^{44}$ As Demirel observes, ". . . the collective identity of the Turks cannot be understood without reference to military and militaristic values such as heroism, courage, war-readiness, and exaltation of martyrdom. Military service is still held in high esteem, despite the increasing number of those who question it." ${ }^{45}$ Such perceptions should facilitate socialization into military values during military service and affect individual's confidence in the military. For instance, Jenkins observes that:

[most Turks] take genuine pride in their reputation as fearsome soldiers and boys are taught that every Turk is born a soldier. This identification with the army is reinforced by national service [military service]. Most young Turkish males regard their 18 months of national service as a rite of passage into manhood. . . Officer cadets are often explicitly told that they are morally superior to civilians in terms of their patriotism and personal rectitude and that the military represents the essence of the national character and is virtually the expression of the national will. ${ }^{46}$

Michaud-Emin also suggests that "much of this cultural brainwashing and these socializing mechanisms [military service] might explain why the Turkish society tenaciously grasps the view that the Turkish military is its most trusted and popular institution. ${ }^{, 47}$ In brief, mandatory military service might play an educational role and socialize individuals into military values and consequently shape their perceptions of the military. Therefore another proposition to be tested should be: 
$H_{6}$ : Those who fulfilled their military service should be more likely to trust the military.

I also take into account the possible impact of several personal factors such as life satisfaction, income and education levels, gender, and age (see Appendix A for variables and measurement). Although I do not have a clear proposition about the impact of each of these factors on societal trust in the military, these factors might also play some role and shape individuals' perceptions of the military in different ways and directions. Therefore these personal factors are also included in the model.

\section{Research Design}

\section{Research Method}

To test the hypotheses presented above, this study uses data provided by the World Values Survey (1999-2000), which is a commonly used data set in the analyses of individual attitudes and values. The sample includes 2,772 Turkish respondents from various parts of the country. ${ }^{48}$ For an easy interpretation, certain recodings were also made in the data set (see Appendix A). The dependent variable measures "confidence in the military," and it ranges from 0 (none at all) to 3 (a great deal). Because the dependent variable is not a continuous variable, using the popular Ordinary Least Squares (OLS) estimates would not be appropriate in this case, because using OLS estimates with a discrete dependent variable would violate the assumption of homoscedasticity (constant variance of the error term across the sample) and of normally distributed error term. Therefore, this study uses the ordinal-probit model as a statistical method. ${ }^{49}$

\section{Statistical Results}

Table 2 reports empirical findings that confirm more than half of the expectations discussed in the theoretical section. First, the statistical results reveal a rather interesting situation-as expected, religion cuts both ways in shaping societal trust in the military. The popularity of the military is clearly lower within pro-Islamic groups, but being a pious individual does not necessarily reduce confidence in the military. Because the military has adopted a tough stance on political Islam since the mid1990s, it is not surprising that its popularity is limited among politically active Islamic groups. However, being religious does not create distrust in the military. This also supports the argument that the military is aware of the fact that Islam is an important part of the Turkish identity. As Heper suggests, "the military is not against Islam as a source of morality. The military makes the crucial distinction between Islam at the level of individual and Islam at the level of the state . . . as far as the military is concerned, it is plausible to be pious and at the same time to be able to conduct secular politics." ${ }^{\text {50 }}$ 
Table 2

Ordinal-Probit Regression Analysis of "Societal Confidence in the Turkish Military"

\begin{tabular}{|c|c|}
\hline Predictors & Dependent variable: Confidence in the military \\
\hline Pro-Kurdish & $\begin{array}{c}-.903189^{\text {**** }} \\
(.1298124)\end{array}$ \\
\hline Pro-Islamic & $\begin{array}{c}-.4345524^{* * * *} \\
(.0828078)\end{array}$ \\
\hline Religious & $\begin{array}{c}.0951652^{* * *} \\
(.0365693)\end{array}$ \\
\hline Nationalist & $\begin{array}{l}.4614121 \\
(.0331186)\end{array}$ \\
\hline Political scale (Left-Right) & $\begin{array}{c}-.0216211 \\
(.0110157)\end{array}$ \\
\hline Support for democracy & $\begin{array}{c}.0718706^{*} \\
(.0332435)\end{array}$ \\
\hline Trust in civilians & $\begin{array}{l}.0761365^{* *} \\
(.026716)\end{array}$ \\
\hline Military service & $\begin{array}{c}-.1037933 \\
(.0951424)\end{array}$ \\
\hline Personal income & $\begin{array}{c}-.0029742 \\
(.0169101)\end{array}$ \\
\hline Life satisfaction & $\begin{array}{c}.0155734 \\
(.0094176)\end{array}$ \\
\hline Education & $\begin{array}{c}-.0391131^{\text {***** }} \\
(.0117352)\end{array}$ \\
\hline Gender & $\begin{array}{c}.1137919 \\
(.0892134)\end{array}$ \\
\hline Age & $\begin{array}{l}.0110588^{\text {***** }} \\
(.0021253)\end{array}$ \\
\hline$\tau_{1}$ & $\begin{array}{c}.0743183 \\
(.1844054)\end{array}$ \\
\hline$\tau_{2}$ & $\begin{array}{c}.4785066 \\
(.1825836)\end{array}$ \\
\hline$\tau_{3}$ & $\begin{array}{l}1.417502 \\
(.1835393)\end{array}$ \\
\hline $\mathrm{N}$ & 2,772 \\
\hline Pseudo $\mathrm{R}^{2}$ & 0.1032 \\
\hline Log likelihood & -2442.9715 \\
\hline LR $\operatorname{chi} 2(6)$ & 539.52 \\
\hline Prob $>$ chi2 & 0.0000 \\
\hline
\end{tabular}

Notes: ${ }^{*} \mathrm{p}<.05 ;{ }^{* *} \mathrm{p}<.01 ;{ }^{* * *} \mathrm{p}<.001$. Robust standard errors are in parentheses. 
Thus there is no doubt that the Turkish military is highly sensitive about secularism, ${ }^{51}$ but this does not mean that the military is against religion itself. The significant variance in the attitudes of pro-Islamic and pious individuals vis-à-vis the military should be a reflection of this situation.

As also expected, the military's popularity is lower among pro-Kurdish groups. This empirical result implies that the military's tough stance on the Kurdish issue has created a certain degree of resentment vis-à-vis the military among certain sections of the Kurdish population. However, again consistent with expectations, the military's popularity is higher among (Turkish) nationalists. This finding confirms that nationalists view the military as an entity representing nationhood and national pride and as the ultimate protector of national ideals and interests. Therefore, they have a greater deal of confidence in the military.

Table 2 also indicates, however, that individuals' ideological affiliations do not matter. In other words, being on the right or left of the political spectrum does not have any significant impact on confidence in the military. This outcome is probably a result of the military's constant attempts to present itself as an institution above politics. As Tachau and Heper assert “. . . ideally, the role of the Turkish armed forces is to remain above and outside politics, and to act as defenders of the Turkish state against its enemies. Politicization and factionalization of the armed forces are to be avoided at all cost." ${ }^{.52}$ This, of course, does not mean that the military stays outside the political realm. What it suggests is that the military is keen to avoid "rightist" or "leftist" labels. As Sakallığlu observes:

Similar to those Brazilian officers from the middle class who perceived themselves as classless soldiers promoting the national interest, the Turkish military has historically shown itself to have sufficient freedom to make and change civilian allies in line with its self-perceived image of being above social dissensus, party politics, and particular interests [emphasis added]. ${ }^{53}$

This empirical finding suggests that the military's image of being a neutral actor or nonpartisan arbiter vis-à-vis ideological struggles in the domestic realm is shared by society.

Another interesting result is that "support for democracy" and "trust in civilians" do not reduce trust in the military. This result seems to suggest that most Turkish citizens regard the military as "part of the democratic process" or as "the ultimate guardian of the democratic system of rule." ${ }^{54}$ Therefore, increasing trust in civilians and in democratic regime does not necessarily reduce confidence in the military. This puzzling situation can be regarded as both good and bad news. It is good news for the military and for the prospects for the consolidation of democracy in Turkey in the sense that if Turkish generals retreat from politics completely and civilians become the only political masters, the military would still enjoy a high degree of 
popularity and prestige in society. In other words, the civilianization process would not necessarily reduce the military's popularity in society. This fact might facilitate democratic control of the armed forces. As Heper and Güney indicate, “. . . sure of its continuing high status in the Turkish polity and society thanks to its avoidance of involvement in day-to-day politics, the Turkish military can afford to forego most of its powers and prerogatives." 55 It is bad news, however, because the consolidation of democracy should take longer in a society in which the military is regarded as part of the political life, and several civilian groups, including certain political parties, turn to the military when a political deadlock emerges in the democracy game. However, further research seems to be necessary to have a better understanding of this puzzling outcome and to see whether this non-zero sum relationship between trust in civilians and civilian institutions vs. confidence in the military is unique to the Turkish case.

The empirical results also show that, unlike the expectation of the military socialization approach, military service does not affect trust in the military. To put it differently, the socialization hypothesis is not supported by the data. This finding supports the argument that the logic of socialization approach is unconvincing. ${ }^{56}$ Krebs, criticizing the logic of military socialization approach, suggested that, "the socialization model problematically conceives of soldiers as passive receivers who lack the capacity for reflection, but cultural systems always contain enough contradictory material so that individuals can challenge hegemonic projects." Krebs further suggests that even if the military successfully inculcates certain values to soldiers, the messages absorbed in one social context are not necessarily portable. ${ }^{57}$ The findings of this study provide strong empirical support to these criticisms.

Finally, statistical results indicate that the level of education and age also matters, but in different ways. Among those with a high level of education, the popularity of the military is lower. Because increasing the level of education would also increase political awareness and sophistication, this finding suggests that, ceteris paribus, improving the level of education in society might contribute to the civilianization process. In regards to the impact of age, compared to younger generations, older generations are more likely to have a high level of confidence in the military. This is probably because these generations witnessed the extreme political instabilities of the 1960s and 1970s, which were ended by military interventions. The ideological, sectarian, and ethnic violence in the 1970s, and the inability of the political system to respond effectively to this fragmentation and polarization, were quite severe, such that when the military intervened and stopped the political meltdown in September 1980 , there was limited reaction to the coup. ${ }^{58}$ It seems that such experiences do affect the way individuals view the military. However other personal factors such as life satisfaction, the level of income, and gender do not have any significant affect on confidence in the military. The following section provides some implications of these empirical findings. 


\section{Conclusion}

Qualitative work is the dominant tendency in Turkish civil-military relations literature. However, the several hypotheses developed and refined by this early qualitative literature have yet to be tested by large- $N$ quantitative studies. As such a quantitative work, this exploratory research was the first attempt to examine the subject of the "societal popularity of the Turkish military," which is taken as given in the existing literature. The Turkish military is a unique case, because despite several military interventions in civilian politics, Turkish society views the military as the most trusted and prestigious institution in the country. This quantitative work is an attempt to deconstruct this high level of societal trust in the military and to achieve a better understanding of the factors and dynamics behind this political phenomenon.

The empirical findings of this study show that although the Turkish military is viewed as highly prestigious and the most trusted institution in society, there is a significant degree of variance in the military's popularity across certain political groups. Although the military's popularity is high among (Turkish) nationalists, it remains limited among pro-Islamic and pro-Kurdish groups. Thus, although respect and confidence in the military is high, it is definitely not uniform across the society. Interestingly, however, religion cuts both ways in the formation of confidence in the military. Pro-Islamic groups do not have much confidence in the strictly secular military, but being a devout Muslim does not reduce the military's popularity. Another interesting finding is that trust in civilians and support for democracy does not necessarily reduce the military's popularity.

One implication of these findings is that if the military cares about its reputation and legitimacy within all segments of society, as most officer corps do ${ }^{59}$ it should avoid involving itself in political struggles among civilian groups. According to the Turkish Armed Forces Internal Service Law (January 1961), the military is responsible for protecting the territorial integrity and the nature of the Turkish regime (including Kemalist principles: particularly secularism and republicanism) (Articles 35 and 85/1). By interpreting this legal language rather broadly, the military has been heavily involved in civilian politics through various formal and informal channels. However, this study provides strong empirical evidence that the military's intervention in the civilian arena on controversial "political" matters, such as those involving political-Islam and the Kurdish issue, do not contribute to its legitimacy and reputation among those groups. The rise of political Islam and Kurdish nationalism/separatism in the 1990s has been the major source of instability in Turkey, and it seems that it will be so in the near future. However, the prominent role of a "distrusted actor" in these sensitive political issues would be counterproductive, discouraging both sides of the conflict to compromise, and causing further delay in efforts to consolidate democracy in the Turkish Republic, which tries to keep its EU bid alive. 


\section{Appendix A: \\ Variables and measurement}

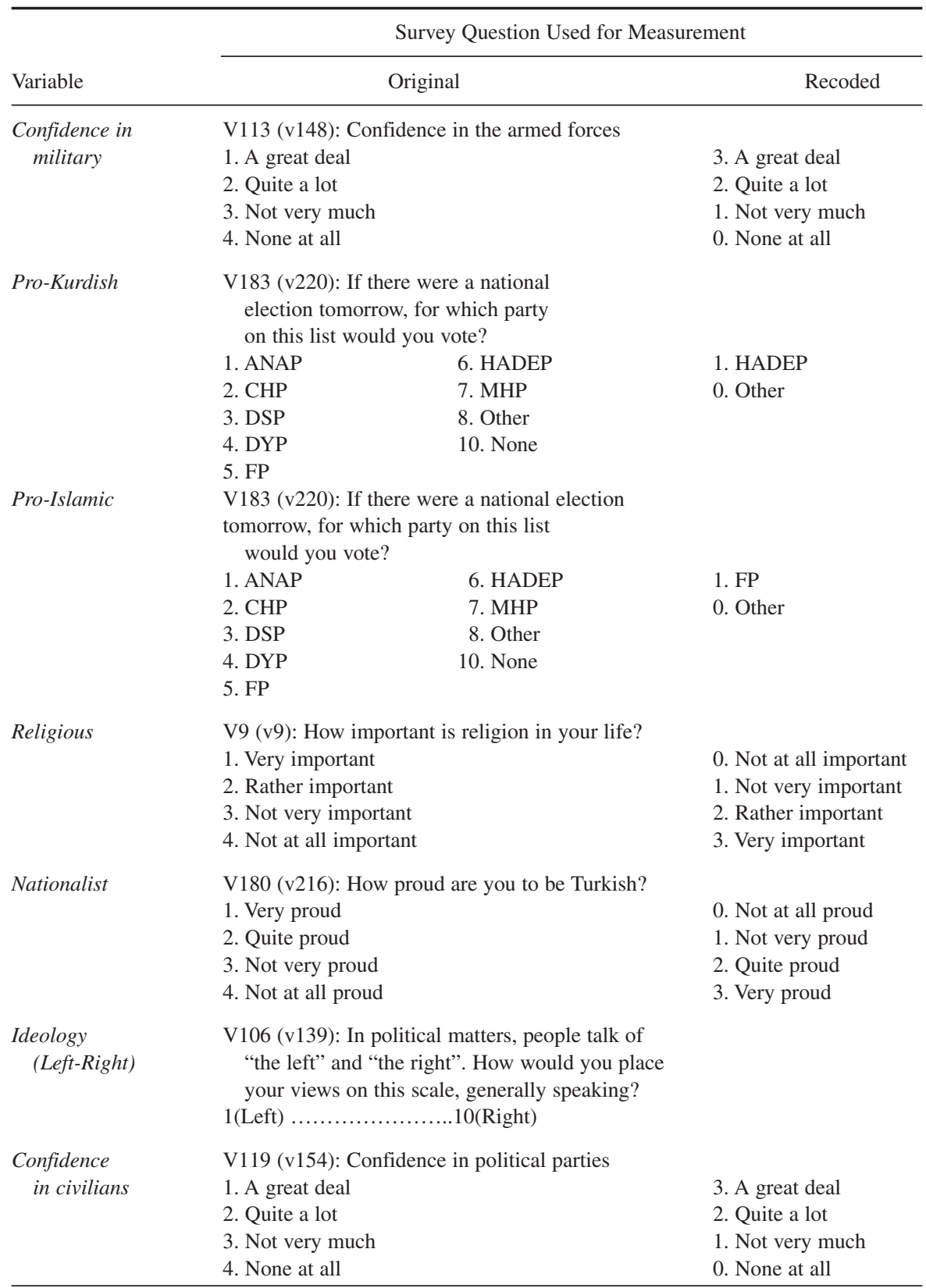




\section{Appendix A: (continued)}

\begin{tabular}{|c|c|c|}
\hline \multicolumn{3}{|c|}{ Survey Question Used for Measurement } \\
\hline Variable & Original & Recoded \\
\hline $\begin{array}{l}\text { Support for } \\
\quad \text { democracy }\end{array}$ & $\begin{array}{l}\text { V136 (v172): Democracy may have problems but } \\
\text { it's better than any other form of government } \\
\text { 1. Strongly agree } \\
\text { 2. Agree } \\
\text { 3. Disagree } \\
\text { 4. Strongly disagree }\end{array}$ & $\begin{array}{l}\text { 3. Strongly agree } \\
\text { 2. Agree } \\
\text { 1. Disagree } \\
\text { 0. Strongly disagree }\end{array}$ \\
\hline $\begin{array}{l}\text { Military Service } \\
\quad \text { (Socialization) }\end{array}$ & & $\begin{array}{l}\text { Constructed by using } \\
\text { 'gender' and 'age' } \\
\text { variables } \\
\text { (0): } 18-25 \text { (military } \\
\text { service not fulfilled) } \\
\text { (1): } 26 \text { and above } \\
\text { (military service } \\
\text { fulfilled ) }\end{array}$ \\
\hline Income & 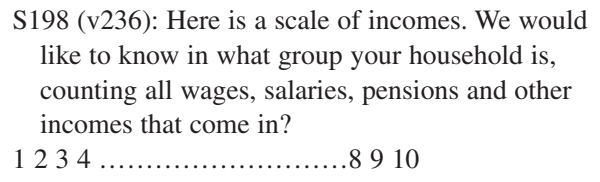 & \\
\hline Life satisfaction & $\begin{array}{l}\text { V49 (v81): All things considered, how satisfied are } \\
\text { you with your life as a whole these days? } \\
1 \text { (dissatisfied)...............10(satisfied) }\end{array}$ & \\
\hline Education & $\begin{array}{l}\text { V189 (v226): What is the highest educational level } \\
\text { that you have attained? } \\
\text { 1: No formal education } \\
\text { 2. Incomplete primary school } \\
\text {... } \\
\text { 9. University-level education, with degree }\end{array}$ & \\
\hline Gender & $\begin{array}{l}\text { V186 (v223): Sex of respondent } \\
\text { 1. Male } \\
\text { 2. Female }\end{array}$ & $\begin{array}{l}\text { 0. Female } \\
\text { 1. Male }\end{array}$ \\
\hline Age & V188 (v225): Age of respondent (18-91) & \\
\hline
\end{tabular}

Source: European and World Values Surveys Four-Wave Integrated Date File, 1981-2004, v.20060423, 2006. The European Values Study Foundation and World Values Survey Association. Website: http://www.worldvaluessurvey.org/. 


\section{Notes}

1. See Necati Polat, "Identity Politics and the Domestic Context of Turkey's European Union Accession," Government and Opposition 41, 4 (2006).

2. Senem Aydın and E. Fuat Keyman, "European Integration and the Transformation of Turkish Democracy," EU-Turkey Working Papers, 2 (2004); Metin Heper and Aylin Güney, "The Military and Democracy in the Third Turkish Republic," Armed Forces and Society 22, 4 (1996); Ümit Cizre, "Problems of Democratic Governance of Civil-Military Relations in Turkey and the European Union Enlargement Zone," European Journal of Political Research 43, 2004; Tanel Demirel, "Soldiers and Civilians: The Dilemma of Turkish Democracy," Middle Eastern Studies 40, 1 (2004); Linda MichaudEmin, "The Restructuring of the Military High Command in the Seventh Harmonization Package and its Ramifications for Civil-Military Relations in Turkey," Turkish Studies 8, 1 (2007); Gareth Jenkins, "Power and unaccountability in the Turkish Security Forces," Conflict, Security and Development 1, 1 (2001); Gareth Jenkins, "Continuity and Change: Prospects for Civil-Military Relations in Turkey," International Affairs 83, 2 (2007).

3. Source: World Values Survey 2000.

4. On this, see also Mehmet Ali Birand, Emret Komutanım (Istanbul: Milliyet Yayınları A.ş., 1986), 201-2. A concise English version of the book is also available: Mehmet Ali Birand, Shirts of Steel: An Anatomy of Turkish Armed Forces (London: I. B. Tauris, 1991).

5. Feroz Ahmad, The Making of Modern Turkey (London and New York: Routledge, 1993); Ümit C. Sakallığlu, "The Anatomy of Turkish Military's Political Autonomy," Comparative Politics 29, 2 (1997); Jeremy Salt, "Turkey's Military Democracy" Current History 98, 625 (1999); Tanel Demirel, "The Turkish Military's Decision to Intervene: 12 September 1980," Armed Forces and Society 29, 2 (2003); William Hale, "Human Rights, the European Union and the Turkish Accession Process," Turkish Studies 4, 1 (2003).

6. Demirel, "Soldiers and Civilians: The Dilemma of Turkish Democracy."

7. Metin Heper, "The European Union, the Turkish Military and Democracy," South European Society and Politics 10, 1 (2005): 33-44; Aylin Güney and Petek Karatekelioğlu, "Turkey's EU Candidacy and Civil-Military Relations: Challenges and Prospects," Armed Forces \& Society 31, 3 (2005); Ersel Aydınlı, Nihat Ali Özcan, and Doğan Akyaz, "The Turkish Military's March Toward Europe," Foreign Affairs January/February, 2006; Zeki Sarigil, "Europeanization as Institutional Change: The Case of Turkish Military," Mediterranean Politics 12, 1 (2007).

8. It should be also noted that, for some observers of Turkish civil-military relations such as Prof. William Hale, the April 27 memorandum seems to not have been endorsed by the Chief of the General Staff, Yaşar Büyükanıt. This was interpreted as an indicator of sharp disagreements at the top of the military on this issue. The statement of the Office of Chief of the General Staff is available at: http://www.tsk.mil.tr.

9. For instance, see European Commission, Turkey 2006 Regular Report (Brussels: Commission of the European Community, 2006), 7-8. Available at: http://ec.europa.eu/enlargement/pdf/key_documents/ 2006/nov/tr_sec_1390_en.pdf. (11.19.07).

10. Samuel M. Huntington, The Soldier and the State: The Theory and Politics of Civil-Military Relations (Cambridge, Massachusetts: Harvard University Press, 1994), 89.

11. Jenkins, "Continuity and Change: Prospects for Civil-Military Relations in Turkey."

12. Özkan Duman and Dimitris Tsarouhas. "Civilianization in Greece versus Demilitarization in Turkey: A Comparative Study of Civil-Military Relations and the Impact of the European Union," Armed Forces and Society 32, 3 (2006): 411.

13. See Demirel, "Soldiers and Civilians: The Dilemma of Turkish Democracy," 128.

14. See Demirel, "Soldiers and Civilians: The Dilemma of Turkish Democracy," 128.

15. Kemal Kirişçi and Gareth M. Winrow, The Kurdish Question and Turkey: An Example of Transstate Ethic Conflict (Portland, OR: Frank Cass, 1997); Ergun Özbudun, Contemporary Turkish Politics: Challenges to Democratic Consolidation (Boulder/London: Lynne Rienner Publishers, 2000); Heinz 
Kramer, A Changing Turkey: The Challenge to Europe and the United States (Washington, DC: Brookings Institution Press, 2000); Murat Somer, "Turkey's Kurdish Conflict: Changing Context, and Domestic and Regional Implications," The Middle East Journal 58, 2 (2004); E. Fuat Keyman and Ahmet ?çduygu, "Introduction: Citizenship, Identity and the Question of Democracy in Turkey," in Citizenship in a Global World: European Questions and Turkish Experiences, ed. E. Fuat Keyman and Ahmet ?çduygu (London and New York: Routledge Taylor and Francis Group, 2005); Kiri?çi and Winrow, "The Kurdish Question and Turkey: An Example of Trans-state Ethic Conflict," 121; Özbudun, "Contemporary Turkish Politics: Challenges to Democratic Consolidation," 141-5; Kramer, "A Changing Turkey: The Challenge to Europe and the United States," XIII-11; Somer, "Turkey's Kurdish Conflict: Changing Context, and Domestic and Regional Implications"; Keyman and İçduygu, "Introduction: Citizenship, Identity and the Question of Democracy in Turkey," 8.

16. Kemal H. Karpat, "The Military and Politics in Turkey, 1960-64: A Socio-Cultural Analysis of a Revolution," The American Historical Review 75, 6 (1970); William Hale, Turkish Politics and the Military (London, New York: Routledge, 1994); Metin Heper and Aylin Güney, "The Military and the Consolidation of Democracy: The Recent Turkish Experience," Armed Forces and Society 26, 4 (2000); Nilefer Narl1, "Civil-Military Relations in Turkey," Turkish Studies 1, 1 (2000); Gareth Jenkins, Context and Circumstance: The Turkish Military and Politics, Adelphi Paper 337 (Oxford, New York: Oxford University Press, 2001); Tanel Demirel, "The Turkish Military's Decision to Intervene: 12 September 1980,"Armed Forces and Society 29, 2 (2003); Demirel, "Soldiers and Civilians: The Dilemma of Turkish Democracy"; Cizre, "Problems of Democratic Governance of Civil-Military Relations in Turkey and the European Union Enlargement Zone" 107; Güney and Karatekelioğlu, "Turkey's EU Candidacy and CivilMilitary Relations: Challenges and Prospects," 441-2.

17. P?nar Tank, "Political Islam in Turkey: A State of Controlled Secularity," Turkish Studies 6, 1 (2005): 9; M. Hakan Yavuz, "Political Islam and the Welfare (Refah) Party in Turkey," Comparative Politics 30, 1 (1997); Sam Kaplan, "Din-u Devlet All Over Again? The Politics of Military Secularism and Religious Militarism in Turkey Following the 1980 Coup," International Journal of Middle East Studies 34 (2002); Tanel Demirel "Lessons of Military Regimes and Democracy: The Turkish Case in a Comparative Perspective," Armed Forces and Society 31, 2 (2005). There are also some exceptions to this general attitude. For instance, in the early 1980s, the military tried to promote Islam as an antidote against the threat of communism. See Yavuz, "Political Islam and the Welfare (Refah) Party in Turkey," 68-70; Kaplan, "Din-u Devlet All Over Again? The Politics of Military Secularism and Religious Militarism in Turkey Following the 1980 Coup," 119; Tank, "Political Islam in Turkey: A State of Controlled Secularity," 10; Demirel, "Lessons of Military Regimes and Democracy: The Turkish Case in a Comparative Perspective," 136.

18. Vali Nasr, "The Rise of Muslim Democracy," Journal of Democracy 16, 2 (2005): 22; and Kaplan, "Din-u Devlet All Over Again? The Politics of Military Secularism and Religious Militarism in Turkey Following the 1980 Coup," 113.

19. See Kaplan, "Din-u Devlet All Over Again? The Politics of Military Secularism and Religious Militarism in Turkey Following the 1980 Coup," 113.

20. Yavuz, "Political Islam and the Welfare (Refah) Party in Turkey," 63; Nasr, "The Rise of Muslim Democracy."

21. Fazilet Partisi (FP) sent 111 deputies to the parliament after national elections in April 1999. However, the party was accused of being a continuation of the banned pro-Islamic Refah Partisi and was closed down by the Constitutional Court in June 2001. When it was closed, the party had 102 deputies in the parliament. Fifty-two of them, also known as traditionalists, established a new party, called Saadet Partisi (Felicity Party, SP), in June 2001. The other half, the reformist wing, joined the Adalet ve Kalkınma Partisi (Justice and Development Party, AKP).

22. For a comparison, see Ziya Öniş, "Political Islam at the Crossroads: From Hegemony to Co-Existence," Contemporary Politics 7, 4 (2001): 281-98; also see Nilüfer Narlı, "The Rise of the Islamic Movement in Turkey," Middle East Review of International Affairs 3, 3 (1999): 38-48; Tank, "Political Islam in Turkey: A State of Controlled Secularity," 7. 
23. See Ali Çarkoğlu, "Religiosity, Support for Şeriat and Evaluations of Secularist Public Policies in Turkey," Middle Eastern Studies 40, 2 (2004).

24. Turkish Daily News, November 16, 1993.

25. Robert Olson, "Introduction," in The Kurdish Nationalist Movement in the 1990s: Its Impact on Turkey and The Middle East, ed. Robert Olson (Kentucky: The University of Kentucky Press, 1996): 1-6; Michael M. Gunter, The Kurds and the Future of Turkey (New York. St. Martin's Press, 1997); M. Hakan Yavuz, "Turkey's Fault Lines and the Crisis of Kemalism," Current History 99, 63 (2000): 33-38; Bertil Dunér and Edward Deverell, "Country Cousin: Turkey, the European Union and Human Rights," Turkish Studies 2, 1 (2001); Svante E. Cornell, "The Kurdish Question in Turkish Politics," Orbis 45, 1 (2001); Fotios Moustakis and Rudra Chaudhuri, "Turkish-Kurdish Relations and the European Union: An Unprecedented Shift in the Kemalist Paradigm," Mediterranean Quarterly 16, 4 (2005): 77-89; Murat Somer, "Resurgence and Remaking of Identity: Civil Beliefs, Domestic and External Dynamics, and the Turkish Mainstream Discourse on Kurds," Comparative Political Studies 38, 6 (2005).

26. Kramer, "A Changing Turkey: The Challenge to Europe and the United States," 40.

27. Neil Hicks, "Legislative Reform in Turkey and European Human Rights Mechanisms," Human Rights Review 3, 1 (2001): 78; Mario Zucconi, Mario, "Turkey's New Politics and the European Union," Ethnobarometer Working Paper April (2003): 7.

28. Murat Somer, "2005a. Defensive- vs. Liberal-nationalist Perspectives on Diversity and the Kurdish Conflict: Europeanization, the Internal Debate, and Türkiyelilik," New Perspectives on Turkey 32 (2005): 74; also see Gülistan Gürbey, "Peaceful Settlement of Turkey's Kurdish Conflict Through Autonomy," in The Kurdish Conflict in Turkey: Obstacles and Chances for Peace and Democracy, eds. Ferhad ?brahim and Gülistan Gürbey (New York: St. Martin's Press, 2000): 64; William Hale, "Human Rights, the European Union and the Turkish Accession Process," Turkish Studies 4, 1 (2003): 116.

29. See Turkish Daily News, December 24, 1997.

30. Author's interview with former Prime Minister Bülent Ecevit (Ankara, December 2005).

31. Hamit Bozarslan, Hamit, "Human Rights and the Kurdish Issue in Turkey: 1984-1999," Human Rights Review 3, 1 (2001): 45-54; Henri J. Barkey and Graham E. Fuller, Turkey's Kurdish Question (New York: Rowman and Littlefield Publishers, Inc., 1998), David Romano, The Kurdish Nationalist Movement: Opportunity, Mobilization and Identity (Cambridge: Cambridge University Press, 2006); Ayşe Betül Çelik and Bahar Rumelili, "Necessary but Not Sufficient: The Role of the EU in Resolving Turkey's Kurdish Question and the Greek-Turkish Conflicts," European Foreign Affairs Review 11 (2006).

32. Güney and Karatekelio?lu., "Turkey's EU Candidacy and Civil-Military Relations: Challenges and Prospects," 449; Duman and Tsarouhas, "Civilianization in Greece versus Demilitarization in Turkey: A Comparative Study of Civil-Military Relations and the Impact of the European Union," 412; MichaudEmin, "The Restructuring of the Military High Command in the Seventh Harmonization Package and its Ramifications for Civil-Military Relations in Turkey," 36.

33. See Cem Ba?levent, Hasan Kirmano?lu, and Burhan ?enatalar, "Empirical Investigation of Party Preferences and Economic Voting in Turkey," European Journal of Political Research 44 (2005): 555-59. However, the last national elections (July 2007) showed that this voting pattern in the region may change. The ruling conservative Justice and Development Party (AKP) received more votes than the openly proKurdish Democratic Society Party (DTP). This interesting development in the region, however, does not create a problem for this measurement strategy, because in the late 1990s (the time period of the survey), the pro-Kurdish HADEP was the main party for pro-Kurdish groups.

34. Jenkins, "Power and Unaccountability in the Turkish Security Forces," 84.

35. Kaplan, "Din-u Devlet All Over Again? The Politics of Military Secularism and Religious Militarism in Turkey Following the 1980 Coup," 117; Demirel, "Soldiers and Civilians: The Dilemma of Turkish Democracy," 140; Jenkins, "Continuity and Change: Prospects for Civil-Military Relations in Turkey," 340-1; see also Birand, "Emret Komutan?m."

36. Sakall?o?lu, "The Anatomy of Turkish Military's Political Autonomy," 154.

37. Huntington, The Soldier and the State: The Theory and Politics of Civil-Military Relations, 94. 
38. Jenkins, "Continuity and Change: Prospects for Civil-Military Relations in Turkey," 339.

39. Michaud-Emin, "The Restructuring of the Military High Command in the Seventh Harmonization

Package and its Ramifications for Civil-Military Relations in Turkey," 34-35.

40. Jenkins, "Power and Unaccountability in the Turkish Security Forces," 85.

41. For a detailed analysis of military socialization, see Birand, "Emret Komutanım."

42. For a critical discussion on this, see Ronald Krebs, "A School for the Nation?: How Military

Service Does not Build Nations, and How It Might," International Security 28, 4 (2004): 90-99.

43. Quoted in Krebs, "A School for the Nation?: How Military Service Does not Build Nations, and How It Might," 91.

44. Narlı, "Civil-Military Relations in Turkey," 118; Kaplan, "Din-u Devlet All Over Again? The Politics of Military Secularism and Religious Militarism in Turkey Following the 1980 Coup," 116.

45. Demirel, "Soldiers and Civilians: The Dilemma of Turkish Democracy," 140; also see Hale, "Turkish Politics and the Military," 328.

46. Jenkins, "Power and Unaccountability in the Turkish Security Forces," 84; A valuable study for detailed information and analyses on this matter would be Birand, "Emret Komutanım."

47. Michaud-Emin, "The Restructuring of the Military High Command in the Seventh Harmonization Package and its Ramifications for Civil-Military Relations in Turkey," 33-34.

48. The survey was conducted by Bo?aziçi University in November-December 2000 in Turkey, in various regions.

49. For more discussion on regression models for categorical variables, see J. Scott Long, Regression Models for Categorical and Limited Dependent Variables (Thousand Oaks: Sage Publications, 1997).

50. Metin Heper, "The Justice and Development Party Government and the Military in Turkey," Turkish Studies 6, 2 (2005): 228.

51. Also see Karpat, "The Military and Politics in Turkey, 1960-64: A Socio-Cultural Analysis of a Revolution," 1671; Frank Tachau and Metin Heper, "The State, Politics and the Military in Turkey," Comparative Politics, 16, 1 (1983); Özbudun, "Contemporary Turkish Politics: Challenges to Democratic Consolidation," 121; Heper and Güney, "The Military and the Consolidation of Democracy: The Recent Turkish Experience," 636; Tank, "Political Islam in Turkey: A State of Controlled Secularity," 8-9.

52. Tachau and Heper, "The State, Politics and the Military in Turkey," 28; Sakallığlu, "The Anatomy of Turkish Military's Political Autonomy," 154.

53. Sakallıoğlu, "The Anatomy of Turkish Military's Political Autonomy," 154.

54. See also Mark Tessler and Ebru Alt?no?lu, "Political Culture in Turkey: Connections among Attitudes toward Democracy, the Military and Islam," Democratization 11, 1 (2004): 35.

55. Heper and Güney, "The Military and Democracy in the Third Turkish Republic," 638.

56. See Krebs, "A School for the Nation?: How Military Service Does not Build Nations, and How It Might."

57. Krebs, "A School for the Nation?: How Military Service Does not Build Nations, and How It Might," 108.

58. Narl? , "Civil-Military Relations in Turkey," 116; Demirel, "The Turkish Military's Decision to Intervene: 12 September 1980," and "Lessons of Military Regimes and Democracy: The Turkish Case in a Comparative Perspective," 252.

59. Tim Jacoby, "For the People, Of the People and By the Military: The Regime Structure of Modern Turkey," Political Studies 51 (2003): 670.

Zeki Sarigil, PhD, is an assistant professor in the Department of Political Science at Bilkent University, Ankara,Turkey. His research interests include institutional theory (comparative and IR), European and Turkish politics, international relations, and Turkish foreign policy. Address for correspondence: Dr. Zeki Sarigil, Department of Political Science, Bilkent University, 06800, Bilkent, Ankara- TURKEY; e-mail: sarigil@bilkent.edu.tr. 